\title{
논문 4
}

\section{태양에너지를 이용한 해수담수화 기술관련 특허 분석}

임은정*, 김성현**

\section{Patents Map on the Desalination Technology Using Solar Energy}

EunJung $\mathrm{Im}^{*}$ and SungHyun $\mathrm{Kim}^{* *}$

Abstract Patent analysis is the extracting knowledge which is needed for the company's research and development strategy through accumulated worldwide patent database. In order to set the future direction corresponding technology which is scheduled to be developed, the technology trends and deployment processes are identified by analyzing results of present patent applications. The patent analysis provides the required results for analyzing present patent applications. In this paper, technology classification for related patent analysis methods and system, and patent analysis for desalination technology using solar energy development was carried out as well. The patents in Korea, USA, Japan, China, and Europe were searched. The technology trend desalination technology using solar energy was analyzed based on patent application year, countries, main applications, and each technologies. The application status of desalination patents showed a tendency to increase slightly. It was found that the number of patent for applied desalination was USA patent 21.0\%, Japan patent 27.0\%, China 24.8\%, EU 2.7\% and Korea patent 24.5\%, respectively.

Key words Patents-Map(특허맵), Desalination Technology(담수화 기술), Solar Energy(태양에너지), Evaporating(증발)

(접수일 2011. 12. 20, 수정일 2012. 2. 17, 게재확정일 2012. 2. 17)

* 고려대학교 공과대학 화공생명공학과 (Department of Chemical and Biological Engineering, Korean University)

E-mail : ejim@korea.ac.kr — Tel : (02)3290-4805—Fax : (02)3290-3644

** 고려대학교 공과대학 화공생명공학과 (Department of Chemical and Biological Engineering, Korean University)

E-mail : kimsh@korea.ac.kr $\square$ Tel : (02)3290-3297 — Fax : (02)926-6102

\section{1. 서 론}

연료전지, 수소에너지, 석탄가스화-액화 기술의 신에너지 와 태양광-태양열, 풍력, 바이오, 폐기물, 지열, 수력-해양 에너지의 재생에너지가 21 세기 전 지구적 에너지 공급을 대 체할 신재생에너지로 분류된다. 다양한 분야에서 연구 개발
되고 있는 에너지 중 21 세기를 선도하는 불루골드, 수자원 기 술 분야의 현황과 방향을 제시하고자 한다. 친화경적이고 전 지구적 차원에서의 물부족 현상을 해소할 수 있는 해수 담수 화 기술 분야의 동향분석과 경제적 효과를 극대화할 수 있는 방안을 모색하고자 한다.

지구전체 수자원 중 음용수는 $2 \%$ 내외로 제한되어 있으므 


\section{논문 4}

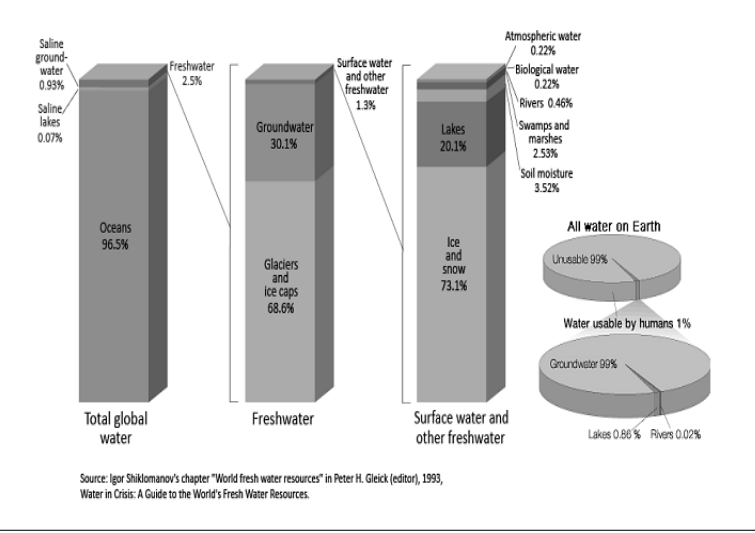

Fig. 1 Distribution of Earth's Water

로 절대적인 양에 해당하는 해수를 생활용수나 공업용수로 이용하기 위하여 염분 제거 및 음용수로의 물로 전환시키고 자 담수화관련 연구가 지속적으로 증가하고 있다(Figure 1). 기후변화와 환경오염으로 가용한 수자원이 고갈되고 있어 해 수담수화 기술 분야는 더욱 활발한 연구가 진행될 것으로 예 측된다. 담수화 산업은 자본집약적 장치산업이며 고부가가치 창출산업으로, 연료전지, 산업용수, 생활용수 등 각종 물 산 업, 대체에너지 등 전방산업에 기초 소재를 공급하는 분야로 기술혁신 등을 촉진하고 있다. 해수담수화는 지난 수 십 년간 의 에너지효율 개선에도 불구하고 화석연료를 대량으로 소비 하는 분야로 남아 있으므로, 신재생에너지를 이용한 해수담수 화 기술의 개발은 절대적으로 필요한 기술이라고 판단된다.

해수담수화 기술은 기원전 선원들이 바다위에서 갈증을 해 소하기 위해 항아리에 바닷물을 끓여 항아리 주둥이 스펀지 에 증발된 수증기를 모운 후 물을 이용하던 원시 기술을 기원 으로 한다. 1940년대 제 2 차 세계대전 때 군부대에 물을 공급 하기 위해 담수시설을 만들기 시작하였고, 전후 담수화 설비 기술로 발전하였다. 1960 년대 역삼투압법이 적용된 담수화 설비가 건설되었고 1970년대 본격적으로 대규모의 담수화 플 랜트가 건설되기 시작했다. 현재, 다단증발법, 다중효용법, 역삼투법, 전기투석법 등의 다양한 담수화 기술이 상용화되 고 있으며 공정혼합방식인 하이브리드 담수화 설비와 바닷물 을 얼려 물을 생산하는 신개념 담수화 기술 개발이 추진되고 있다.

대부분의 해수담수기술은 화석연료를 사용하여 염분을 제 거함으로 그 과정에서 배출되는 각종 유해물질로 온실가스 배출과 기후변화를 야기하고 있다. 최근에는 선진국을 중심
으로 탄소배출권이 새로운 경제적 요소로 대두되면서 청정기 술 방식으로의 전환을 모색하고 있다. 이에 해수담수기술 중 청정기술 분야에 가까운 태양에너지를 활용한 담수화 기술의 연구동향과 기대가능성이 높은 분야를 검토하고 특허가 어떤 기술을 포함하고 있는지 분석하여 기술의 방향을 제시할 뿐 아니라 주요출원인을 분류하고자 한다. 또한 핵심 특허 및 권 리분석으로 회피방안도 제시하고자 한다.

특허분석에 의한 기술동향 파악은 기존에 수행되었던 관련 기술의 연구내용 파악뿐만 아니라, 향후 연구의 방향을 설정 하는데 중요한 자료로 활용될 수 있다. . 또한 분석을 통하여 개발하고자하는 기술이 기존의 특허를 침해하는지 파악할 수 있고, 공백기술 분석으로 향후 개발되어야 할 연구과제도 제 시할 수 있다 ${ }^{3)}$

본 특허동향조사 연구에서는 태양에너지로부터 열과 전력 을 이용하여 담수화하는 기술을 핵심기술 요소로 추출하였 다. 태양에너지를 이용한 해수담수화에 관한 특허수준 및 독 창성을 분석함으로써 우리나라의 기술 수준, 선진기업의 연 구개발 동향 및 핵심특허 현황 등을 파악하여 객관적인 연구 방향과 특허정보를 제시하였다.

\section{2. 특허제도 및 분석방법}

\section{1 특허제도}

특허맵(Patents-Map) 분석 결과를 이해하려면 우선, 특 허제도를 이해해야 산출된 결과를 이해할 수 있다. 검색대상 은 모든 국가가 아니라 한국, 미국, 일본, 유럽 그리고 최근 들어 다수의 특허를 출원하고 있는 중국 특허를 분석 대상으 로 한다.

우리나라는 일본 제도와 유사하며 출원공개제도와 등록공 고제도가 있다. 따라서 공개시점을 기준으로 특허를 검색하 였다. 과거에는 요지부분만 공개하는 방식이었으나 컴퓨터 데이터베이스 관리기술이 발달하면서 전자출원제도 도입으 로 전문공개가 공개시점에도 이루어지는 것으로 제도가 바뀌 었다. 미국에는 2000 년 이후, 공개제도가 일부 도입되기는 하였으나 제한적이고 모두 공개되지 않고 등록된 것은 모두 공개된다. 그러므로 미국 특허 검색에서는 미국 등록 특허와 
공개 특허를 각각 분석하여 기술의 경향을 파악한다. 유럽특 허제도(EPO)는 지역특허제도로 근접한 지역 내의 국가끼리 조약을 체결하여 지역특허에 가입한 국가끼리 인정해 주는 제도로 출원시 미리 출원국을 지정하고 $\mathrm{EPO}$ 서치 부서에서 심사를 한다. 서치심사 후 공개하고 실체심사과정을 거쳐 거 절사정이 되지 않으면 등록된다. $\mathrm{EPO}$ 특허도 출원공개 시에 특허가 공보에 실리게 된다. 유럽특허출원은 비교적 중요한 특허에 대하여 유럽지역 출원을 목적으로 한다. 비교적 중요 하지 않은 특허는 유럽 내 특정 국가별로 출원하게 된다. 그 러므로 $\mathrm{EPO}$ 특허는 기술적 가치가 높다 ${ }^{4)}$.

\section{2 정의 및 기술분류}

담수화 공정으로는 역삼투법(reverseosmosis membrance), 증류법(distillation) 그리고 전기투석법(electro dialysis)으 로 분류된다. 역삼투법은 조작이 용이하여 최근 연구가 많이 되고 있지만, 증발법보다 에너지 소비량이 적고 막의 내구성 에 문제가 있으며 해수의 충분한 전처리를 요한다. 증류법은 생산수의 순도가 높지만 에너지 소비량이 많다. 그리고 전기 투석법은 온도변화에 대응이 용이하지만 대규모장치에 부적 합함으로 일부 분야의 연구만이 진행 중인 기법이다. 증발법 은 해수담수화 기술 중 가장 오래된 기술로서 가장 널리 사용 되고 있다. 증발법 담수화 설비는 현재 전세계의 담수화 설비 중 약 $70 \%$ 를 차지하고 있다. 증발법으로 만들어진 담수의 염 도는 이론적으로 제로이기 때문에 보일러용 초순수의 제조 등에도 응용되고 있다.

태양에너지 해수담수화 시스템은 해수담수기, 열원으로 공 급되는 단일 진공관형 태양열 시스템, 유체 구동펌프 등의 전 원 공급을 위한 태양광 발전시스템, 제어 시스템과 해수담수 기로 해수의 공급을 위한 해수 공급시스템으로 구성된다. 경 제 및 산업적 측면에서 역삼투압 방식의 유지, 보수 문제 등 으로 고비용 담수설비 대체효과와 신재생에너지 보급 증대로 에너지 절감, 수입대체효과가 예상된다. 미국은 태양열발전, 일본은 온수기, 유럽은 대규모 집단난방시스템 형태로 선진 국에서는 국가별 특성에 맞는 기술을 중점적으로 개발, 보급 하고 있으며 국내에서는 보급확대를 위한 온수기 등의 저온 활용 요소기술에 중고온 시스템 개발에 중점적으로 연구되고 있다. 태양에너지 해수담수화 기술은 태양에너지로만 열과 전기를 공급하면서도 시스템의 구조가 간단하고 유지 보수가
Table 1. Classification of Technologies for Reverse Osmosis Membrane

\begin{tabular}{c|c}
\hline Technology & Classification \\
\hline Technology of the evaporating & Evaporating Desalination \\
\cline { 2 - 2 } desalination plant with solar energy & Technology of the solar energy \\
\hline
\end{tabular}

적은 시스템으로 개발된 것이다. 따라서 전력공급이 되지 않 거나 부족한 지역에 적합하며, 특히 도서지방의 담수부족문 제 해결에 중요한 역할을 수행할 것이다 ${ }^{5}$. 태양에너지를 이 용한 해수담수화와 직접적으로 관련된 기술과 태양에너지를 이용하거나 응용한 수처리 기술로 분류하였다(Table 1).

\section{3 증발법 종류}

증발법 담수화설비는 증발기의 형상과 열원의 이용방법에 따라 다중효용방식, 다단플래쉬방식, 증기압축방식 등으로 분류된다. 다단증발법(Multi-Stage Flash)은 순간적으로 증 기를 방출하는 플래싱(Flashing) 현상을 이용해 해수를 증기 로 만들어 준 후에 응축시켜서 담수를 생산하는 방법을 말한 다. 여러 단계에서 순차적으로 증발-응축 현상을 만들어주기 때문에 대용량화가 가능하여 중동에서는 대부분 MSF 방식의 담수플랜트로 건설되고 있다. 단 내부는 진공상태로 염수의 포화 압력보다 낮기 때문에 플래쉬 증발로 증기가 발생되며 이 증기는 단 상부의 열 교환기에서 응축되어 담수가 생산된 다. 해수 가열기에서 사용되는 열원은 주로 스팀이며, 이 스 팀은 주로 발전 플랜트의 스팀 터빈이나 열회수 보일러에서 받기 때문에 MSF 플랜트는 주로 발전 플랜트와 함께 건설되 며, 이렇게 발전 플랜트와 함께 건설되는 담수 플랜트를 발전 -담수(Power \& Water) Co-generation plant 혹은 Dual purpose plant라고 한다.

다중효용법(Multi-Effect Distillation)은 다단증발법의 단 (Stage)과 유사한 일련의 용기 안에서 담수화 과정이 일어나 며, 관(Tube) 내에서 응축하는 수증기와 관 외부를 흐르는 농염 수 간의 잠열 교환에 의한 증발과 용기 내의 압력을 낮추는 원리 를 이용하는 방법을 말한다. 증기압축법(Mechanical Vapor Compression Distillation)은 증발실에서 발생한 증기를 압 축기 등으로 압축하여 증기온도를 상승시킨다. 고온증기는 가열용 증기로 사용되기 때문에 장치는 소형화가 가능하여, 장차 선박용 또는 가정용으로 유망하다. 


\section{논문 4}

\section{4 특허검색 대상}

특허출원 동향 분석을 하기 위하여 관련된 모든 특허를 검 색하여 분석하는 것이 이상적이지만 모든 것을 수집하는 데 는 한계가 있으므로 우선 자료의 검색 범위를 설정할 필요가 있다 ${ }^{6)}$. 태양에너지를 이용한 해수담수화 관련 특허의 전반적 인 흐름파악에 초점을 두고 특허를 분류하였다. 특허를 출원 연도별, 국가별, 기술별, 출원인별로 분류하여 각 부문별 특 수건수, 중요특허, 출원건수와 출원인수 변화의 상관관계 등 에 대한 분석을 수행하였다.

본 연구에 이용된 통계분석 기초 자료는 연구 성과의 파급효과 및 연구의 필요성을 고려하여 한국(http://www. kipris.or. kr/), 일본(http://www.jpo.go.jp/), 미국(http://www. uspto.gov/), 유럽(http://www.epo.org/), 중국(http://www. wips.co.kr), 2010 년까지 출원된 특허를 검색 $\mathrm{DB}$ 를 이용하여 분석하였다 ${ }^{711)}$. 해수담수화 역삼투막 기술분야를 특허분석대상으로 하였으 며, 2001년 01월 2010년 12월까지 출원 공개된 한국, 일본, 유럽, 중국 및 미국 공개특허와 2010년 12월까지 출원 등록 된 미국등록특허를 분석 대상으로 하였다. 한국, 일본 및 유 럽특허는 출원일 기준으로 분석하였고, 미국특허는 등록일 기준으로 분석하므로 최근 데이터도 유효하여, 정량분석은 1990년부터 최근 자료도 검토하였다(Table 2).

본 분석에서는 양적인 통계를 의미하는 정량분석과 각 특 허가 갖는 기술적인 내용을 의미하는 정성분석으로 나누어 분석하였다. 정량분석 방법은 특허를 출원연도별, 국가별, 기술별 및 출원인별로 분류하여 각 부문별 특허건수 및 증가 율 등으로 구분하여 분석을 수행하였고, 이를 통해 세계의 특 허동향과 우리의 수준을 비교하고, 역삼투막 분야에서 세부 기술 분야별 연구개발 현황과 주요 기업을 살펴봄으로써 국 가차원의 연구개발 및 국제협력의 필요성 등에 대한 기초자 료를 제시하였다. 정성분석 방법으로는 역삼투막 분야에 대

Table 2. Classification of Technologies for Reverse Osmosis Membrane

\begin{tabular}{c|c|c}
\hline Country & Period & Raw Data \\
\cline { 1 - 1 } Korea & \multirow{3}{*}{$1990 \sim 2010$} & 134 \\
\cline { 1 - 1 } Japan & 148 \\
\cline { 1 - 1 } Chana & & 136 \\
\cline { 1 - 1 } Europe & & 15 \\
\cline { 1 - 1 } USA & & 115 \\
\hline
\end{tabular}

한 기술의 흐름을 파악하고, 핵심특허는 별도로 심층적인 권 리분석을 수행하여 권리범위 현황 파악 및 이를 통해 공백기 술을 도출하였다.

\section{3. 거시적 동향분석}

\section{1 주요국가의 전체 특허 동향}

기술동향을 파악하는 방법은 기존에 수행되었던 관련 기술 의 내용을 파악하는 것 이외에도 연구내용이 중복되는 것을 사전에 방지하여 향후 연구의 방향을 설정하는데 중요한 자 료로 활용될 수 있다 ${ }^{12)}$. 선행특허를 검색하고, 추출된 해외특 허와 국내특허를 검토하여 국내특허의 기술수준을 분석하였 다. 기술적 수준의 판단을 위해 핵심특허 각각을 분석하는 특 허장벽 분석, 핵심특허의 출원수를 정량적으로 비교하는 핵 심 특허 수 비교, 핵심특허의 유사특허의 유사도를 정성적으 로 비교하는 핵심특허 유사도 비교 분석도 도출하였다.

Figure 2 는 미국의 등록특허와 공개특허 분석과 주요 출원

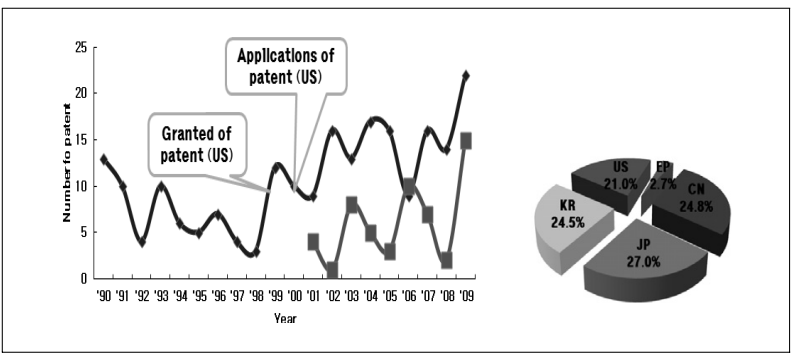

Fig. 2 Trend and share of the applied patents by main applicants

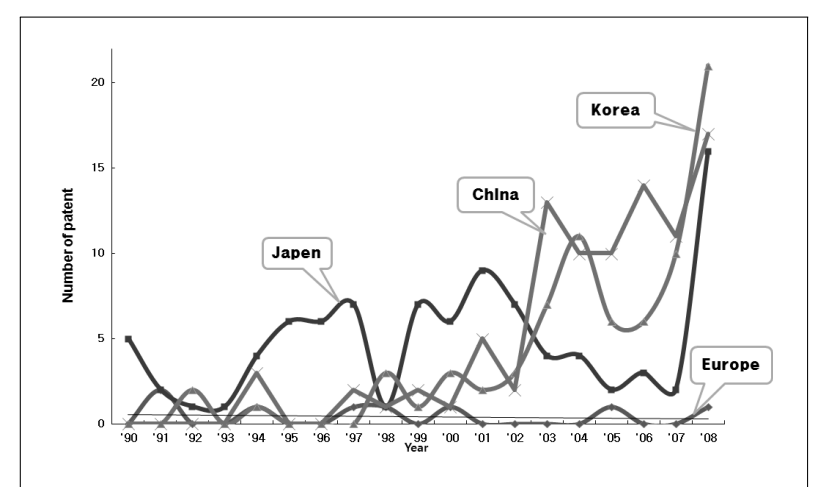

Fig. 3 Trend of the applied patents by the countries (JP, KR, CN, EP) 
국가별 특허건수에 관한 그래프이고, Figure 3 은 한국, 일본, 중국, 유럽의 년도별 경향을 도시한 것이다. 분석구간은 한국, 일본, 중국, 유럽 특허는 출원년도를 기준으로 1990 2009, 미국등록특허(1990 2009)와 미국공개특허( 2009)로 하였 다. 출원국가별 출원분포는 일본이 전체의 $27 \%$ 로 가장 많은 출원을 하였으며, 다음으로는 한국특허로 전체의 $24.5 \%$, 중 국은 $24.8 \%$ 가 출원되었다. 그리고 미국등록 특허는 $21.0 \%$ 로 한국과 중국보다 상대적으로 낮게 출원되었으며, 유럽은 $2.7 \%$ 로 다른 국가에 비하여 현저히 적은 출원건수를 나타내 고 있다.

미국은 1990년 초반부터 2009년 까지 증감을 반복하며 지 속적으로 조금씩 증가하는 추세를 보이고 있다. 미국등록특 허는 2000 년도 초반에 지속적으로 특허 등록공개가 이루어 진 것으로 분석된다. 해수담수화 기술별 특허출원을 보면 일 본이 모든 기술면에서 특허출원이 많음을 알 수 있다. 그 다

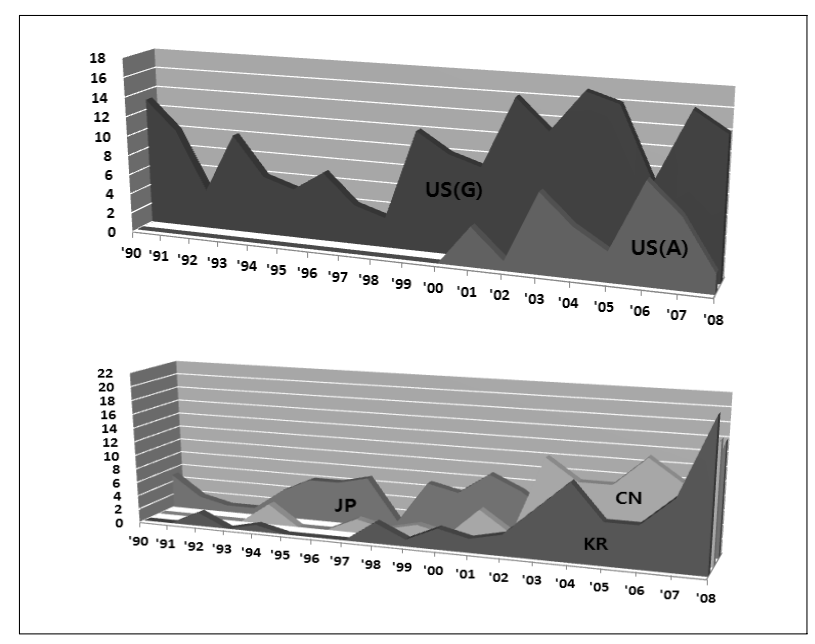

Fig. 4 Trend of the applied patents by the countries

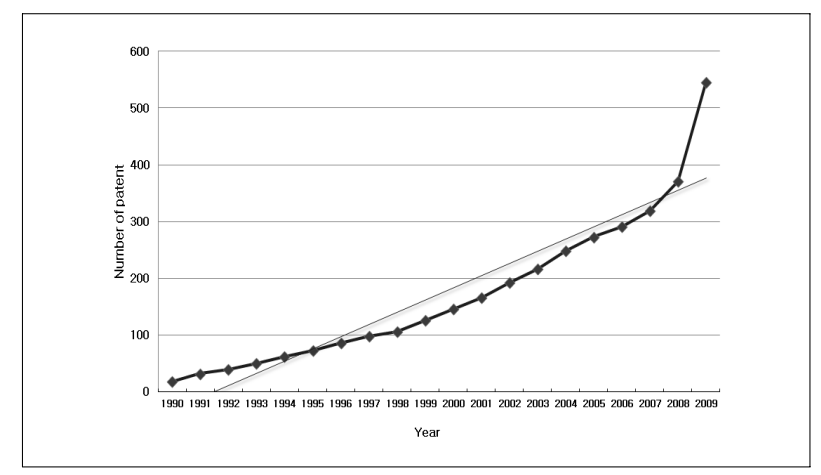

Fig. 5 Annual trend of the accumulated patents
음으로 중국과 한국, 미국 순으로 나타났다. 일본이 1990년 대 중반부터 특허가 증가하기 시작하였으며 2007년 이후 급 속도로 증가하고 있다. 한국은 2000년대 중반부터 특허가 증 가하기 시작하였으며 후반까지 꾸준히 출원되다가 일본과 마 찬가지로 2008년도에 출원이 급등하고 있다. 유럽은 1990년 후반부터 출원되고 있지만 그 건수가 매우 적어 정확한 경향 을 제시할 수 없다(Figure 3).

Figure 4는 미국등록과 공개특허, 일본, 중국, 한국의 연 도별 특허동향을 나타내는 그래프이고, Figure 5 는 전체 특 허출원 누적건수이다. 한국, 미국, 유럽의 연도별 기술트렌 드를 살펴보면, 지속적으로 증가하는 추세이며, 일본은 1990 년대 후반에 상승세를 보였으나 2000년대 초반에는 감소하 다가 다시 증가하여 꾸준한 출원을 이어오고 있다. 한국과 중 국특허의 그래프가 대체적으로 비슷한 경향을 나타내고 있음 을 알 수 있다(Figure 4). 각국의 공개 및 등록 특허에 대하여 그 유효 특허 건수를 도표화하여 정량화함으로써 전체적인 기술 동향을 파악하기 위한 분석방법으로 Figure 5 를 보면 20년 동안 지속적인 증가 추세를 보이고 있으며 2000년대 중 반 이후까지 연구가 활발히 진행되다가 2009년 이후 특허 출 원이 급등하는 현상을 보이고 있다. 이는 선진국을 중심으로 수자원 확보와 해수담수화 공정의 효율성 향상으로 담수화에 대한 중요성이 부각되고 있으며, 태양에너지를 응용한 관련 기술 특허가 급증했기 때문이다. 중국은 2000년대 이후 기술 적 측면에서의 활발한 연구개발로 인한 경제적 효율성이 향 상됨으로 본격적인 특허출원이 이루어지고 있다.

\section{2 포트폴리오로 본 해수 담수화 역삼투막 기술발전의 위치}

포트폴리오 기본 모델은 유효 데이터를 일정한 시간 간격 으로 출원연도별 분포를 고려하여 5 년으로 나누어 출원건수 와 출원인수 변화의 상관관계를 통해 기술의 위치를 분석하 는 방법으로서, 그래프 상에서 화살표의 진행 방향은 시간의 흐름을 나타내며, 화살표 진행 방향의 모양과 기준 그래프 발 전기, 성숙기, 퇴조기, 부활기의 모양을 비교하여 기술위치 를 판단하게 된다. 특허출원건수와 출원인수간 상관관계를 통해 기술의 발전, 성숙 및 퇴조단계를 한눈에 파악할 수 있 는 기술추이 포트폴리오로, 발전기는 출원인 수와 특허출원 건수가 모두 증가하는 단계로서 이는 시장선점을 위해 기술 


\section{누는 4}
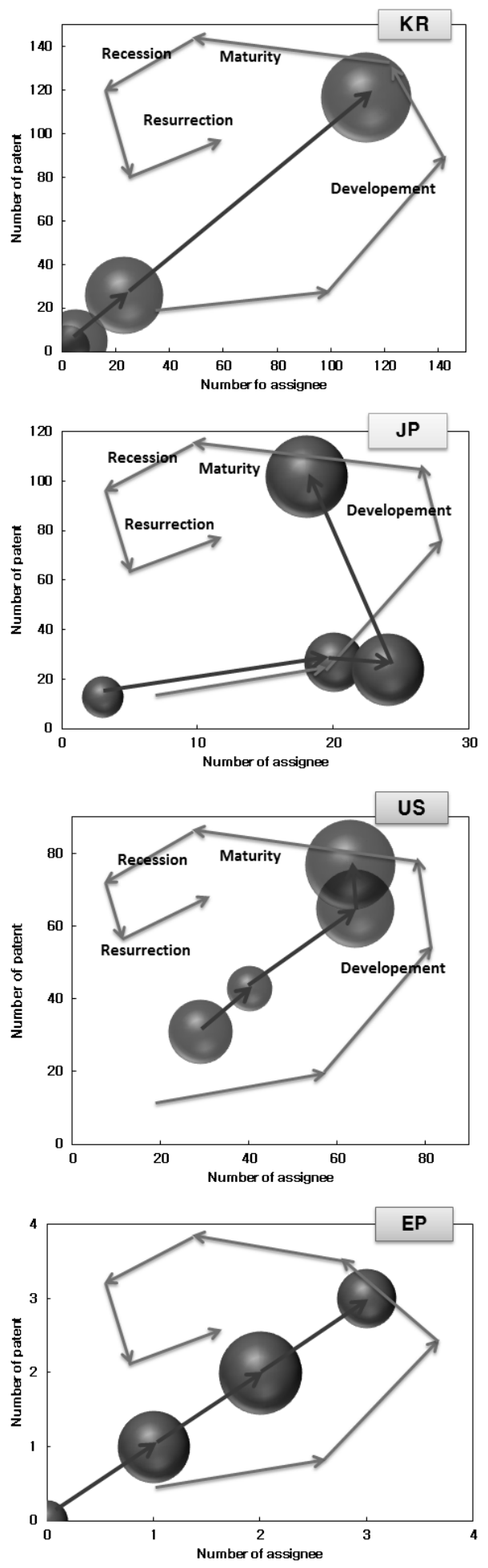

Fig. 6 Portfolio of detailed upgrading technologies (patent analysis spans based on the year of application:

1990 1994, 1995 1999, 2000 2004, 2005 2009)
개발에 참여하는 기업수가 점차 증가하며 각 기업의 기술개 발활동이 활발하게 이루어지는 것을 의미하고, 성숙기는 기 술개발이 포화된 상태로서 시장에 참여하는 기업이 포화상태 에 이르며 기술개발활동은 점차 감소하는 현상을 의미한다. 그리고 퇴조기는 사양기술로 기술개발에 참여하는 기업수와 기술개발활동이 점차 감소하는 것을 뜻하고, 부활기는 새로 운 기술의 등장으로 기술개발이 다시 활발해지면서 특허출원 수가 증가함을 의미한다. 포트폴리오 분석은 거시적인 출원 추세를 보기위한 분석이므로 모집단의 건수가 적을 경우에는 오차범위에 비해 연도별 편차가 크기 때문에 명확한 수치로 판단되지는 않는다.

Figure 6에서 전체 특허를 기준으로 포트폴리오를 도시한 결과 태양에너지를 이용한 해수담수화 기술의 위치는 출원건 수도 증가하고 출원인수도 증가하는 발전기에 있음을 알 수 있다. 관련 기술에 대한 출원이 지속적으로 발생하게 될 것으 로 판단되며, 이와 관련하여 기존 출원인의 친환경적 기술개 발이 활발하게 진행될 것으로 예측된다. 미국, 유럽, 한국, 중국특허의 동향은 발전기적인 형태를 보이고 있으며, 일본 은 발전기에서 성숙기로 진행되는 양상을 나타내고 있다. 이 는 전체적인 동향과 크게 차이나지 않는 것으로 나타났으므 로 한국, 미국, 일본, 중국, 유럽 모두 담수화 분야의 연구가 더욱 활발할 것으로 기대된다.

\section{3 출원인별 특허동향 분석}

Figure 7은 미국과 일본의 주요 출원인별 출원건수를 나타 낸 그래프이다. 미국의 경우, Genedics Clean Energy, LLC 가 태양에너지를 이용한 출원건수가 많고 SECNAV가 5 건으 로 나타났으며 대부분의 특허가 기업과 연구소, 대학을 중심 으로 다양한 출원인으로 특허출원이 이루어지고 있다. 일본 은 MITSUBISHI에서 태양에너지를 이용한 관련 특허를 출원 하고 있다. 이는 포트폴리오 분석에서도 알 수 있듯이 특허출 원 건수도 증가하고 출원인수도 증가하는 발전기에서 출원인 수가 변화 없는 성숙기로 점차 변화하고 있음을 뜻한다. 국내 에서는 1990년부터 개인을 중심으로 담수화연구가 진행되어 왔으며 2000년 중반이후 물산업 관련 기업과 한국에너지기 술연구원에서 다수의 특허가 출원되고 있다. 2008년 이후 출 원건수가 급등하는 현상을 보임으로 연구기관과 기업에서도 더 많은 연구가 진행될 것으로 기대된다. 


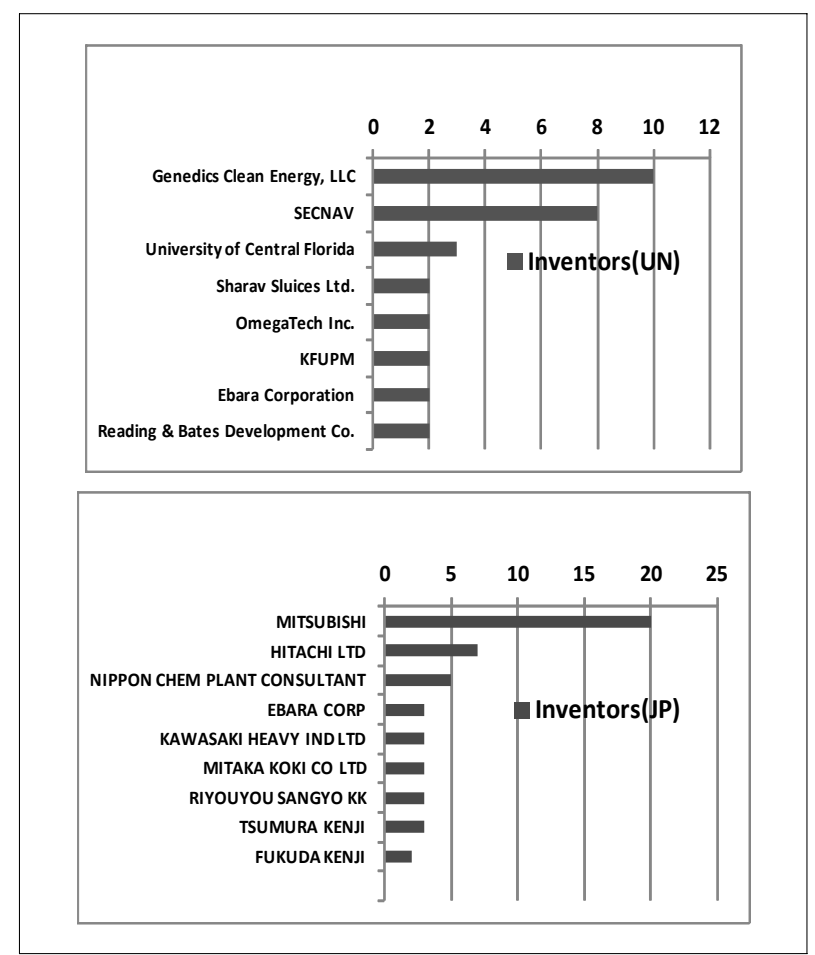

Fig. 7 Main Applicants by country. WIPS DB

\section{4 연구동향 분석}

\subsection{1 국내 태양열 이용기술 현황}

우리나라는 1970년대 초부터 대학과 연구소를 중심으로 연구를 시작하여 1988년부터 대체에너지개발 촉진법에 따라 정부차원에서 태양열 이용기술 개발을 추진 중이며, 기술개 발 동향은 보급확대를 위한 태양열 온수기 등 저온 활용 요소 기술에 대한 효율 및 신뢰성 향상과 태양열 이용 기술의 확보 를 위해 중고온 등 시스템 개발에 중점 추진 중이다. 1980년 대 해수담수화 기술 중, 친환경적 담수화 기법인 태양에너지 를 이용한 방법 및 장치관련 특허가 출원되었고 초기에는 담 수 장치 및 작동방법 등의 기본적인 공정기술 개발에 중점적 으로 진행되었다. 2000년 이후, 태양에너지를 이용한 공정 효율 향상을 위한 각종 특허가 출원되었다. 한국에너지 기술 연구원의 증발법에 의한 해수담수화 장치는 소비되는 에너지 를 최소화하기 위하여 증발관에서 발생되는 저온의 증기잠열 을 응축시키지 않고 기계적으로 압축하여 자체 가열원으로 재이용하는 방식이다. 그리고 기계적 증기재압축 증발방식을 이용한 해수담수화 장치 및 부산물로 얻어지는 고농도의 염
Table 3. Patent list by country. WIPS DB (KR,US)

\begin{tabular}{|c|c|c|}
\hline Pub. No. & Title & Inve-ntor \\
\hline 1978-880882 & Solar distillation apparatus & US(G) \\
\hline 1978-881613 & Method and apparatus for solar distillation & US(G) \\
\hline 1980-204560 & $\begin{array}{l}\text { Thermal gradient humidification-dehumidification } \\
\text { desalination system }\end{array}$ & US(G) \\
\hline 1980-221373 & Distillation apparatus with solar tracker & US(G) \\
\hline 1985-783332 & Desalinating drip-irrigation system & US(G) \\
\hline $1987-064400$ & System for desalinization of saltwater & US(G) \\
\hline $1993-019247$ & $\begin{array}{l}\text { Desalination plant for salt water using solar } \\
\text { energy }\end{array}$ & US(G) \\
\hline $2001-0006723$ & $\begin{array}{l}\text { The method of seawater desalination by } \\
\text { utilization of solar heat and it's equipment }\end{array}$ & $K R(A)$ \\
\hline $2004-559696$ & $\begin{array}{l}\text { Distillation methods and devices in } \\
\text { particular for producing potable water }\end{array}$ & US(A) \\
\hline 2004-895357 & Solar seawater desalting apparatus & US(A) \\
\hline $2005-0078477$ & $\begin{array}{l}\text { The marine water heating and marine } \\
\text { fresh-water generator and water-purifying } \\
\text { system using solar heating energy }\end{array}$ & $K R(A)$ \\
\hline $2006-0053857$ & Desalter of seawater & $\mathrm{KR}(\mathrm{A})$ \\
\hline $2006-228090$ & Tower for the distillation of seawater & US(A) \\
\hline $2006-586704$ & ergy seawater desalination device & US(A) \\
\hline $2006-795810$ & Solar Desalination Apparatus & US(A) \\
\hline $2008-0090075$ & $\begin{array}{l}\text { Distillation Method and Apparatus for All } \\
\text { Sort of Water to include Salt Water Using } \\
\text { the Solar Heat }\end{array}$ & $K R(A)$ \\
\hline $2008-0128570$ & $\begin{array}{l}\text { Desalination apparatus using solar heat } \\
\text { and fan }\end{array}$ & $K R(A)$ \\
\hline $2008-863561$ & $\begin{array}{l}\text { Energy-Saving Type Apparatus For } \\
\text { Producing Freshwater }\end{array}$ & US(A) \\
\hline 2009-0049496 & The Sea Water Evaporation Device & $\mathrm{KR}(\mathrm{A})$ \\
\hline $2009-0058036$ & $\begin{array}{l}\text { Desalination apparatus by solar thermal } \\
\text { system }\end{array}$ & $\mathrm{KR}(\mathrm{A})$ \\
\hline 2009-0061196 & $\begin{array}{l}\text { Evaporative Desalination Apparatus of Sea } \\
\text { Water Using Phase Changing Fluids }\end{array}$ & $K R(A)$ \\
\hline $2009-0061197$ & $\begin{array}{l}\text { Evaporative Desalination Apparatus of Sea } \\
\text { Water Using Heatpipe }\end{array}$ & $K R(A)$ \\
\hline $2009-0072955$ & $\begin{array}{l}\text { System Making Fresh Water from Sea Water } \\
\text { using Solar Energy and Small Hydroelectric } \\
\text { Power }\end{array}$ & $\mathrm{KR}(\mathrm{A})$ \\
\hline $2009-0106613$ & $\begin{array}{l}\text { Multi Effect Distiller using Solar Thermal } \\
\text { Energy }\end{array}$ & $\mathrm{KR}(\mathrm{A})$ \\
\hline 28723 & $\begin{array}{l}\text { Solar Thermal-Combinded Desalination } \\
\text { System }\end{array}$ & $K R(A)$ \\
\hline $2009-414076$ & $\begin{array}{l}\text { Apparatus For Desalinization } \\
\text { Utilizingtemperature Gradient/Condensation } \\
\text { And Method Thereof }\end{array}$ & US(A) \\
\hline
\end{tabular}

수를 이용하여 고품질의 소금을 제조하는 방법이 출원되었 다. 개인출원인을 중심으로 유류나 전기와 같은 에너지 없이 태양에너지만을 이용하여 물의 양수, 열 교환, 수증기 재 가 


\section{논문 4}

열 및 증발의 복합공정으로 해수 또는 각종 물을 고효율로 증 류시키는 방법 등에 관한 효율 향상을 위한 연구가 다수 이루 어 졌다(Table 3).

열교환기를 이용한 절감형 담수화 장치와 태양에너지와 소 수력을 이용한 결합형 시스템, 태양광열 복합모듈을 이용한 특허가 주를 이루고 있다. 태양열과 태양광을 이용한 장치는 담수화장치 내에서의 상변화로 해수를 증발시켜 담수화하는 방식으로, 태양광을 태양열 집열부 및 담수부에서 사용되는 집열 펌프, 상변화 매체 유동펌프, 담수 유동펌프 등의 구동 전력을 이용하고 있다. 기업이나 개인출원인을 중심으로 태 양에너지를 담수화에 이용하는 방식인 해수 정화장치와 발전 과 담수시스템을 결합한 방식, 태양열과 히트 펌프열을 이용 하거나 증기 재응축 담수화방식, 증기 가열가압응축 담수화 방식, 태양열 병합 담수화 시스템에 관한 특허가 출원되었다. 태양열을 이용한 특허는 대부분 시스템 구축과 에너지 절감 을 위한 시스템 결합방식으로 출원되고 있다.

태양열을 이용하여 해수를 가열하되 해수의 수면에 바람을 공급하여 해수의 증발을 촉진시킴으로써 담수량을 증대시킬 수 있고, 설비와 운전 비용이 작게 소요된다는 특징으로 하는 설비연구와 태양열 에너지와 태양광 에너지를 동시에 이용하 는 제조장치, 증발기 및 담수장치 전체의 외벽에 단열재를 추 가설치하여 열손실을 최소화시킨 히트파이프를 이용한 태양 열 증발식 해수 담수화 장치 등 복합 기술을 이용한 장치가 개발되었다. 그리고 2000년 후반부터 온실가스 배출 문제가 대두됨으로 인해 탄소배출 저감을 위한 방향으로 연구가 진 행되고 있다. 최근, 국내 기업은 태양열 다중 복합 시스템' 으로 역삼투식 해수담수 플랜트와 태양열을 이용한 증발식 해수담수 플랜트를 조합한 하이브리드 방식으로 세계 최초로 태양열을 활용한 담수화 설비로 수자원 확보를 위한 태양열 활용한 담수플랜트를 착공했다. 향후 태양에너지를 이용한 해수 담수화 특허 출원 동향은 한 가지 방식의 공정이 아닌, 효율성 향상과 경제성을 고려한 복합적이고 친환경적인 형태 의 특허가 출원될 것으로 전망된다.

\subsection{2 국외 태양열 이용기술 현황}

미국은 연구소와 대학을 중심으로 태양에너지를 이용한 담 수화 시스템 연구가 활발히 진행되고 있다 ${ }^{13)}$. MIT의 필드 및 우주 로봇 연구소 연구팀이 휴대용 태양광 담수화 시스템을
고안했다. 신속하고 손쉽게 식수를 구할 수 있는 유용한 기술 로, 태양광 전지판의 동력으로 고압 펌프가 작동하며 여과막 으로 바닷물을 통과시킨다. 직사광선이 없을 경우 배터리 전 원으로 작동하는 기존의 태양광 담수화시스템과 달리 이 시 스템은 흐린 날씨에도 효율적으로 작동한다. 미국은 태양열 발전, 일본은 온수기, 유럽은 대규모 집단난방시스템 형태로 선진국에서는 국가별 특성에 맞는 기술을 중점적으로 개발, 보급하고 있다.

일본은 담수설비, 태양전지 원료 등 신기술로 가격경쟁력 의 일환으로 주로 고효율 장치개발 특허가 다수 출원되고 있 다. 중국도 여러 도시에서 해수의 담수화 사업 실험을 벌여왔 다. 그렇지만 기존의 해수담수화 기술은 그 투자비용이 만만 치 않은데다 에너지 소모가 지나쳐서 담수가격이 매우 높아 널리 보급되기는 어려운 실정이었다. 중국은 열에너지 전환 효율이 낮은 문제를 해결할 수 있는 특허 출원을 기반으로 태 양에너지의 에너지 효율 증대를 위한 특허 출원이 주를 이루 고 있다. 해수를 담수화할 때 소모되는 에너지를 최저로 낮추 어 담수생산의 원가를 크게 내림으로 효율성이 높은 태양광 과 같은 신재생에너지 분야에 주력하고 있는 추세이다.

\section{4. 결론 및 향후 전망}

출원국가별 출원분포는 일본 $27 \%$ 로 가장 많으며, 한국 $24.5 \%$, 중국 $24.8 \%$, 미국등록 $21.0 \%, \mathrm{EP} 2.7 \%$ 로, 미국은 1990년 초 반부터 2009년 까지 지속적으로 증가하는 경향을 보이고 있 다. 해수담수화 기술별 특허출원을 보면 일본이 모든 기술면 에서 다수의 특허가 출원되었다. 일본이 1990년대 중반부터 특허가 증가하기 시작하였으며 2008년 이후 급속도로 증가 하고 있다. 한국은 1990년대 중반부터 특허가 증가하기 시작 하였으며 2000년도 중반까지 꾸준히 출원되다가 일본과 마 찬가지로 2009년도에 출원이 급등하고 있다.

태양에너지를 이용한 해수담수화 기술의 위치를 포트폴리 오 도시 결과를 통해 출원건수도 증가하고 출원인수도 증가 하는 발전기에 있음을 알 수 있다. 관련 기술에 대한 출원이 지속적으로 발생하게 될 것으로 판단되며, 이와 관련하여 기 존 출원인의 친환경적 기술개발이 활발하게 진행될 것으로 예측된다. 미국, 유럽, 한국, 중국특허의 동향은 발전기적인 
형태를 보이고 있으며, 일본은 발전기에서 성숙기로 진행되 는 양상을 나타내고 있다. 전체적인 동향과 크게 차이나지 않 는 것으로 나타났으므로 한국, 미국, 일본, 중국, 유럽 모두 담수화 분야의 연구가 더욱 활발할 것으로 기대된다.

미국과 일본의 주요 출원인별 출원건수를 살펴보면, 미국 의 경우 대부분의 특허가 기업과 연구소, 대학을 중심으로 다 양한 출원인으로 특허출원이 이루어지고 있다. 국내에서는 1990 년부터 개인을 중심으로 담수화연구가 진행되어 왔으며 2000년 중반이후 물산업 관련 기업과 한국에너지기술연구원 에서 다수의 특허가 출원되고 있다. 미국은 태양열발전, 일본 은 온수기, 유럽은 대규모 집단난방시스템 형태로 선진국에 서는 국가별 특성에 맞는 기술을 중점적으로 개발, 보급하고 있으며 국내에서는 보급확대를 위한 온수기 등의 저온활용 요소기술에 중고온 시스템 개발에 중점적으로 연구되고 있 다. 2008년 이후 출원건수가 급등하는 현상을 보임으로 연구 기관과 기업에서도 더 많은 연구가 진행될 것으로 기대된다. 2000년 후반부터 온실가스 배출 문제가 대두됨으로 인해 탄 소배출 저감을 위한 방향으로 연구가 진행되고 있다.

\section{References}

[1] 임은정, 김성현, 한국환경분석학회지 제14권 (제3호) 172 178, (2011).

[2] 이기봉, 전상구, 노남선 외, 한국공업화학회지, Vol. 19, No. 6. December, 592-599 (2008)

[3] Brinn, M.W., Fleming, J.M., Hannaka, F.M., Thomas, C.B., Beling, P.A., Systems and Information Engineering Design Symposium, 2003 IEEE 24-25 April, 2003 Page(s) 1 6.

[4] 원정욱, 전학성, 박태웅, 전자통신동향분석 제 17 권 제 5 호 2002, 10].

[5] 곽희열, 한국에너지 기술연구원, 2006년 과제보고서.

[6] 강경석, 김태일, 이호일 외, 한국공업화학회, Vol. 21, No. 2. April, 188-194 (2010).

[7] KIPRIS, http://www.kipris.or.kr

[8] http://www.jpo.go.jp

[9] http://www.uspto.gov

[10] http://www.epo.org

[11] WIPS, http://www.wips.co.kr

[12] 김용현, 이원수, 김개호 외, 한국공업화학회, Vol. 21, No. 4, 372-376 (2010).

[13] 박병국, KOTRA 산업동향, (2009).

\section{임 은 정}

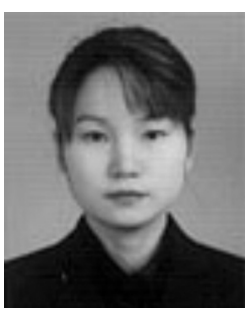

1998년 건국대학교 지리학과 이학사 2001년 연세대학교 지구시스템과학과 이학석사 2006년 고려대학교 통계조사학과 통계학석사 2007년 고려대학교 환경시스템공학협동 (화공생명공학과) 공학박사
현재 고려대학교 공과대학 화공생명공학과 연구교수

(E-mail : ejim@korea.ac.kr)

\section{김 성 현}

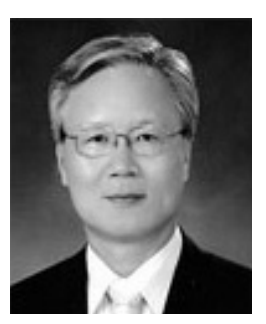

1978년 고려대학교 화학공학과 공학사

1981년 University of Southern California 공학석사

1986년 University of Southern California 공학박사
현재 고려대학교 공과대학 화공생명공학과 교수

(E-mail : kimsh@korea.ac.kr) 